Martha J. Bailey has published the second book in her series on women scientists-American Women in Science: 1950 to the Present: A Biograpbical Dictionary (ABC-CLIO, 1998). This includes 300 women in science, engineering, mathematics, and social and behavioral sciences. The first volume in the series is American Women in Science: Colonial Times to 1950: A Biographical Dictionary(1994).

William R. Burk, librarian at the John N. Couch Biology Library at the University of North Carolina at Chapel Hill (UNC-CH), has been elected a Fellow of the Ohio Academy of Science. He is one of 48 scientists, engineers, and educators chosen. Fellows are members of the Ohio Academy of Science who have rendered some special service to the academy or have macle extensive, productive scientific, technological, or educational contributions to society. Burk cofounded the Triangle Area Mushroom Club, a nature group that hunts and identifies local fungi and mushrooms. He has written 15 journal articles and a book on North American Gasteromycetes (mushrooms). Burk has served the UNC-CH since 1979.

Diane Warner, assistant librarian and cataloguer at the Texas Tech University, will learn about British cataloguing and reference procedures at the John Rylands University Library at the University of Manchester, England, in an exchange program. Stefanie Hundsberger, of the University of Manchester, is temporarily fulfilling Warner's cataloguing responsibilities at the Texas Tech University Library.

\section{Appointments}

James R. Adair Jr. has been appointed direc tor of the ATLA Center for Electronic Texts in Religion (ATLA CETR). CETR is a research and development division of ATLA, developed by the association in collaboration with and located at Emory University in Atlanta, Geor- gia. Initially Adair will serve as project director of ATLA's journal digitization project ATLAS. He served as manager of Information Technology Services for Scholars Press in Atlanta from 1994-98. Since 1996 he has taught as an adjunct professor at Mercer University in Mason, Georgia.

William J. Crowe has been appointed Kenneth Spencer Research Librarian at the University of Kansas (UK), effective July 1, 1999. Crowe will oversee Spencer library's collection of rare books, manuscripts, archives and other origi-

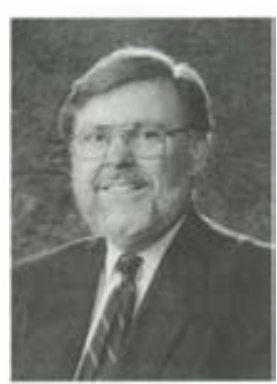

William J. Crowe nal materials, as well as the Robert J. Dole Archive, which will be housed at the Dole Institute for Public Service and Public Policy. Crowe will also take a leading role in fundraising for UK's libraries and information services. After service in the libraries at Ohio State University and Indiana University during the previous two decades, Crowe came to the UK in 1990 as dean of libraries. In 1996 he was named vice chancellor for information services in addition to his responsibilities as dean of libraries.

Derick Dreher has been appointed director of the Rosenbach Museum \& Library. Dreher, who joined Rosenbach in April 1997 as curator, has been working as interim director and curator since August 1998. As interim director, Dreher has worked with the building committee and the Board of Trustees to plan all aspects of the museum's impending renovation. As director he will work with the trustees, staff, and architect to renovate the building at 2008

Ed. note: To ensure that your personnel news is considered for publication, write to Ann-Christe Young, Production Editor, C\&RL News, 50 E. Huron St., Chicago, IL 60611-2795; e-mail: ayoung@ala.org; fax: 312-280-2520. 
DeLancey, which was purchased in 1993, and join it with the existing museum. He has published on a variety of subjects, including prints and drawings ranging from Dürer to Daumier, and has spoken internationally at conferences on drawings, rare book, libraries, and the art of memory.

Marilu Goodyear has been appointed vice chancellor for information services at the University of Kansas.

Gerald R. Lowell has been appointed the Kenneth and Dorothy Hill university librarian at the University of California (UC) at Berkeley. He comes to Berkeley from UC San Diego (UCSD) where he served as university librarian and associate vice chancellor for Academic Information Technology. There he was instrumental in increasing the library's endowment, he introduced the concept of shared decision-making within the UCSD Libraries, and he introduced the first campus-wide library user survey. Prior to his five years at UCSD, he was associate university librarian and director for Technical Services at Yale University Library from 198693 and chief of Cataloging Distribution for the Library of Congress from 1984-86. He also served as vice president and managing director for North America for Faxon and head of the Serials Division Title II-C Serials Project for the University of Washington Libraries.

Sarah M. Pritchard has been appointed university librarian at the University of California (UC) Santa Barbara, effective April 28,1999 . Pritchard comes to UC from Smith College, where she was director of libraries. Prior to this position, she worked for the Library of Congress and the Association of Research Libraries. Pritchard has an extensive record of professional service: She served two terms as an elected member of the Council of the ALA; board member of the New England Chapter of the Association of College and Research Libraries; chair of several sections and committees within the ALA; and senior trustee of the Leroy C. Merritt Humanitarian Foundation. She was elected a member of the first executive board for the new statewide multitype library network in Massachusetts. She has written more than 40 articles and reviews, and lectured internationally on library administration, collection development, and other professional issues.

Wilba Swearingen was named director of the Louisiana State University Medical Center (LSUMC) Libraries in New Orleans. Swearingen began her career in medical librarianship at LSUMC when she helped open the new Dental Library in 1971. After spending nearly 15 years as a librarian and publisher's representative in Wisconsin, Louisiana, and throughout the southwest, she returned to LSUMC in 1988 to take the position as associate director. Since then, she has served as acting director twice, in 199495 and from September 1997 until her appointment as director.

Carole Bell has been appointed head of the acquisitions department at the University of Maryland in College Park

Kathleen A. Berry has accepted the position of microforms librarian at Boston College.

Terry Brandsma has heen appointed Information Technology Librarian at the University of North Carolina in Greensboro.

Jeffrey “Jeff” S. Bullington has been appointed Librarian I, reference librarian/bibliographer at the University of Kansas.

Damon Camille has joined Rice University as the director of the Document Delivery and Fee-Based Services department.

Janet Cellucci is now associate university librarian for Collection Services at Boston College.

Luozhu Cen has been appointed reference librarian at Butte College in Oroville, California.

Lynn Chmelir is the new assistant director for Public and Research Services at Washington State University.

Jean Delauche has been appointed research/information services librarian for the American Society for Quality.

Burton Van Name Edwards has been appointed senior cataloger for the Burns Library at Boston College.

Thomas Garnett is now head of the Information Systems Division at the Smithsonian Institution Libraries.

Marie Seymour-Green has been appointed coordinator of serials in the Acquisition Department of the University of Delaware. 
Marilyn Grush has been appointed coordinator of Interlibrary Loan/Document Delivery in the Access Services Department of the University of Delaware.

Howard Harris has been appointed director of the Information Technology Division at the University of Maryland in College Park.

Charles Howell is the new curator for the Library of American Broadcasting at the University of Maryland in College Park.

Geraldine "Geri" L. Hutchins is the head of the Information Technology Services Department for Texas Tech University.

Sidney $F$. Huttner has been appointed head of the department of Special Collections at the University of Iowa in Iowa City.

Kelly M. Jordan has been appointed humanities librarian for Digital Resources Center at Pennsylvania State University.

Zahra Kamarei has been appointed Brauer librarian at the University of North Carolina at Chapel Hill.

Valery King has been appointed Government Information and Social Sciences librarian at Oregon State University in Corvallis.

Anne Langley has been appointed head of the Chemistry Library at Duke University.

Sharron Manassa has been appointed research/information services librarian for the American Society for Quality.

Judy C. Sevilla-Marzona is now reference librarian at the Rio Hondo College in Whittier, California.

Paula McMillen has been appointed Social Sciences Librarian at Oregon State University in Corvallis.

Lisa Roberts has been appointed assistant reference librarian at the University of North Carolina in Greensboro.

Marianne Ryan is the new head of Government Documents/Maps at the University of Maryland in College Park.

Brenda Parrish Sibley is the new cataloger for Troy State University in Troy, Aldbama.

Bryan Skib is the new European Studies Collection specialist for the Humanities Team/associate curator for the University of Michigan in Ann Arbor.

Margit J. Smith is now head of Technical Services at the University of San Diego.
Elizabeth Sweeney is now Irish music librarian for Boston College.

Joseph D. Thompson has accepted the position of African American Studies Archivist and Resource specialist in the Rare Book, Manuscript, and Special Collections Library at Duke University.

Joe Toth has been appointed Government Information and Social Sciences Librarian at Oregon State University in Corvallis.

Laura Turner has been appointed technical services librarian at Washington and Lee University in Lexington, Virginia.

Debra Warner has been appointed head of Information Services at the W. E. Laupus Health Sciences Library at East Carolina University in Greenville, North Carolina.

Vernon "Skip" Warnick has been appointed Webmaster at the University of Maryland in College Park.

Teresa Weisser has been appointed electronic records librarian at Millersville University of Pennsylvania.

\section{Retirements}

Oleta Armstrong has retired, after 27 years at Texas Tech University, as assistant head of Information Services for reference.

Charles Kauderer retired in December after almost 17 years as library director at Manatee Community College. Armed with a master's degree in library education from the University of Iowa, Kauderer went to Lakeland College in Sheboygan, Wisconsin, for his first library job. He also worked at an Illinois community college, a Chicago high school, and Regis University in Denver before coming to Manatee. He was on the College Center for Library Automation's Advisory Board, where he served as vice-chair, and on the Executive Committee. He served on several standing committees and task forces including the Standing Committees on Bibliographic Quality Control and Resource Management Strategy.

\section{Deaths}

Marvin H. Scilken, retired director of the Orange (New Jersey) Public Library, mem- 
ber of the governing council of the ALA and frequent contributor to the New York Times "Letters to the Editor," died February 3 at age 72 . Scilken retired from the Orange Public Library in 1993 after 29 years of service. He had served on the ALA's 200-member governing council since 1981. He was also the editor and publisher of the newsletter " $U^{*} N^{*} A^{*} B^{*} A^{*} S^{*} H^{*} E^{*} D^{*}$ Librarian." Scilken entered library work after seeing a public notice in the New York Times in which the State of New York offered to train people to become librarians at the state's expense. Scilken took them up on the offer and attended Pratt Institute, where he was later honored as Alumnus of the Year. In 1966, Scilken testified before the U.S. Senate Subcommittee on Anti-Trust and Monopoly on the alleged price fixing of library books. As a result of the hearings, more than 1,000 lawsuits were filed and millions of dollars recovered by local libraries. Shortly before he retired, Scilken led a successful campaign to end Bell Atlantic's plan to charge libraries for non-Bell Atlantic telephone directo- ries. Scilken was attending the Midwinter Meeting of the ALA in Philadelphia at the time of his apparent heart attack.

Eldon Tamblyn, professor emeritus at Portland State University (PSU), passed away at his home in Portland of an apparent heart attack at the age of 70 . Tamblyn was head cataloger at PSU from 1967 until his retirement in 1996. During that period he led the catalog unit through several major changes as the catalog moved from cards to microfilm and then to its present online form. Before joining PSU, he was head Slavic cataloger at Stanford University (1964-67) and was Slavic cataloger at Duke University (1962-64). Tamblyn compiled the indexes of several books and publications including CERL and CERL News from 1975-90 and he continued to compile the indexes through vol. 55, 1994 and edited the indexes for vol. 56-58 (1995-97). He was a member of several professional organizations including the ALA (since 1968), Oregon State System of Higher Education, and the Western Library Network.

\section{"The Past is Prologue." \\ -Wm. Shakespeare}

These words convey a philosophy long held by Northern Micrographics. It is a philosophy that the tapestry of our past must be preserved, since all learning is based upon past insights.

This preservation takes both the digital and physical form, from CD-ROM to acid-free, reference quality, bound books.
And so we would ask this question of you:

"What do you knote that's
worth saving?"

Call us and discover more about how we can further preserve the fabric of past knowledge and future insight.

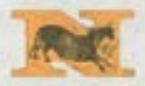

Northern Micrographics, Inc. wutu.normicro.com

\section{Call Toll Free: $1-800-236-0850$}




\section{Advertiser index}

$3 \mathrm{M}$

Cover 4

Academic Book Center

A I A

222

American Institute of

Cover 3

Chemical Engineers

American Psychological

208

Association

American Theological

Library Association

Annual Reviews

Association of Research

Libraries

190

Baker \& Taylor

204,225

Blackwell's Book Services

Blackwell's Information Services 179

Cambridge Scientific Abstracts 150

Chadwyck-Healy

207

Chemical Abstracts Service Cover 2

$\mathrm{CHOICE}$

170

CISTI

153

EBSCO

Elsevier Science

171

Emery-Pratt

156

Endeavor Info. Systems

180

Engineering Information, Inc. 178

ESRI

223

Faxon/Information Quest

213

Fitzroy Dearborn

152

Gale Research

172

Graphics Press

147

164

226

H. W. Wilson

183

Hoover's, Inc.

191

InfoEN

224

International Specialized

Book Services

McGraw-Hill

149

Minolta

Northern Micrographics

OCLC

192,210

Ovid Technologies

221

PAIS

161

196

R.R. Bowker

162,215

Roper Center

216

ScienceDirect

214

151

SilverPlatter

198

195

\section{AGGREGATED.} INTEGRATED.
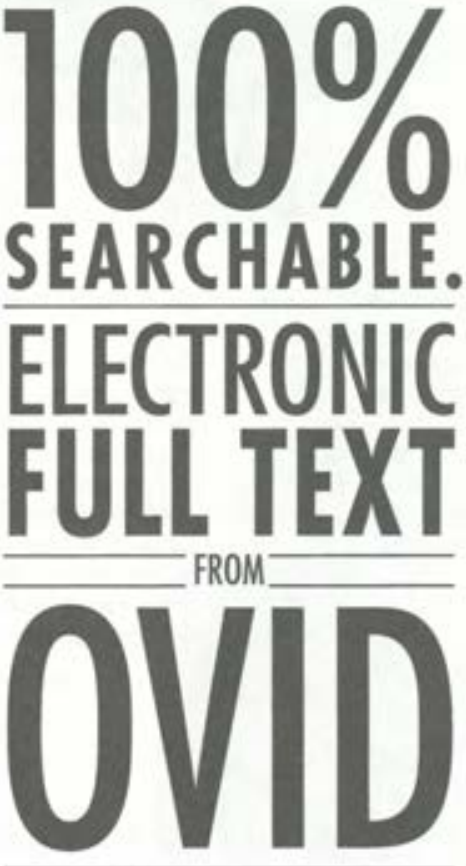

If you're looking for an electronic full text solution for your institution, look no further. Ovid offers the only truly integrated solution in the business. With hundreds of full text STM journals and 90 popular bibliographic databases - consolidated under a single interface and joined by over a million links-Ovid provides a unique aggregated, integrated, and fully-searchable solution that unlocks the full power of electronic information.

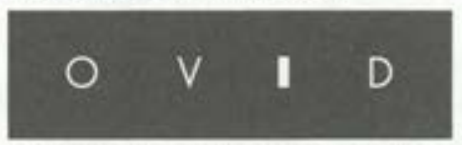

JOIN OVID AT BOOTH \#509 FOR A DEMO! 


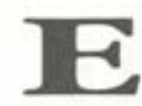

\title{
A Universe of Information
}

\author{
with the Aerospace Database- \\ available online or on $C D-R O M$.
}

\begin{tabular}{|c|c|}
\hline $\begin{array}{l}\text { Worldwide Access } \\
\text { to Aerospace } \\
\text { Information } \\
\text { Search through } \\
\text { nearly } 35 \text { years of } \\
\text { accumulated } \\
\text { material in aero- } \\
\text { space and related } \\
\text { sciences. }\end{array}$ & $\begin{array}{l}\text { Over Two Million } \\
\text { Entries Online and } \\
\text { Growing } \\
\text { Representing docu- } \\
\text { ments from over } 50 \\
\text { countries in over } 20 \\
\text { languages all } \\
\text { easily searched by } \\
\text { subject, keyword. } \\
\text { authot publication } \\
\text { date, accession } \\
\text { number and morel }\end{array}$ \\
\hline
\end{tabular}

Worldwide Access

A erospace

accurnulated

material in aero-

space and related

sciences.

\author{
An Unparalleled \\ Resource You Can \\ Rely on \\ Contains abstracts \\ of journal articles. \\ books. technical \\ reports, and con- \\ ferences, including \\ reports issued by \\ NASA, other U.S. \\ government agen- \\ cies, international \\ organizations, \\ universities, and \\ private industry.
}

Trusted by

Professionals Just Like You

Brought to you by AlAA, the world s largest professional society devoted to the progress of engineering and science in aviation and space.

\section{THREE EASY WAYS TO ACCESS THE AEROSPACE DATABASE-CALL TODAYI}

\section{For online services and} CD-ROM:

Dialog Corporation 2440 El Camino Real

Mountain View. CA 94040 $800 / 334-3564$ or

$415 / 254-8800$

Fax: $415 / 254-8350$
For online services: STN International 2540 Olentangy Rlver Road Columbus, $\mathrm{OH} 43210$ $800 / 753-4227$ or $614 / 447-3731$

Fax: $614 / 447-3751$
Cambridge Scientific Abstracts 7200 Wisconsin Avenue Bethesda, MD 20814 301/961-6750 Fax: $301 / 961-6720$ E-mail: market@csa.com Internet:

http://www.csa.com

\section{Now available via online service or on CD-ROM!}

$\$ 98-250$

\section{AEROSPACE} ACCESS
OAIAA.

American Institute of

Aeronautic and Astronautics 


\section{If a Picture is Worth a Thousand Words, a Map Must be Worth a Million}

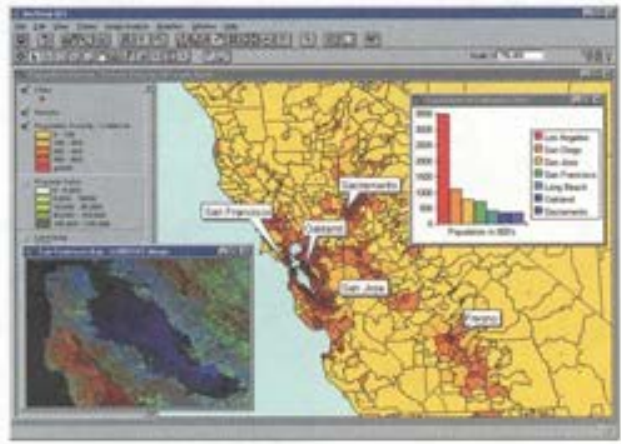

Libraries are the campus nerve center, tying all departments and disciplines together by their common need for information. As a clearinghouse for all kinds of information, libraries need to provide tools that make information easy to access and understand. One of these is a geographic information system (GIS). A GIS turns ordinary databases into interactive maps and provides tools to query those databases in ways not possible with traditional spreadsheets. A GIS is useful to students and researchers in any discipline from agriculture to zoology. Providing a GIS workstation at the library makes these tools available to the entire campus community, not just one or two departments.

ESRI offers a range of GIS packages for libraries, from ArcView ${ }^{*}$ GIS to the Spatial Database Engine ${ }^{n}$ $\left(\mathrm{SDE}^{\mathrm{*}}\right)$ —client/server software for managing large spatial databases. For more information about $\mathrm{ESRI}^{\circ}$ GIS solutions, call us today.

\section{1-888-531-9220 www.esri.com/libraries E-mail: info@esri.com}

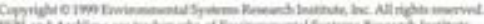

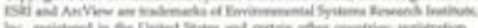

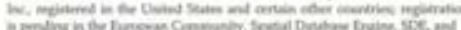

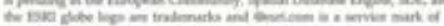




\section{InTERNATIONAL SPECIALIZED Book Services}

\section{-Your Global Source-}

Continuing a 25-year tradition, ISBS supplies scholarly titles from over sixty outstanding international publishers in a variety of subjects: history, literature, political science, science, technology, legal theory, psychology, international affairs, and regional studies.

\section{Australia \& New Zealand \\ Australian Gov't Pub. Service \\ Fremantle Arts Centre Press \\ Indra Publishing \\ Monash Asia Institute \\ U. of New South Wales Press \\ U. of Otago Press \\ $\mathrm{U}$, of Queensland Press}

U, of Western Australia Press

\section{England Ireland \& Wales}

Alpha Press

Attic Press

Cork U. Press

Four Courts Press

Free Association Books

Frank Cass Publishers

Hart Publishing

Hisarlik Press

Horizon Scientific Press

Intellect

Irish Academic Press

Littman Library of Jewish

Civilization

Liverpool U. Press

Royal Irish Academy

Saqi Books

Shelf Books

Stanley Thornes

Sussex Academic Press

Vallentine Mitchell
Welsh Academic Press

Woburn Press

Y Lolfa

\section{Other regions}

Akademiai Kiado (Hungary)

Canadian Gov't Pub. Center

(Canada)

Center for Romanian Studies

(Romania)

Hong Kong U. Press (Hong

Kong)

Nordic Academic Press

(Sweden)

Odense U. Press (Denmark)

Poetry Salzburg (Austria)

Times Academic Press

(Singapore)

U. of Natal Press (Republic of

South Africa),

ISBS is pleased to announce that we are now the exclusive North American distributor for Free Association Books, Hart Publishing, Intellect, Royal Irish Academy, \& Stanley Thornes.
New Directions in Transactional Analysis Counselling $1-85343-429-9 \mathrm{p} / \mathrm{b} \$ 24.95$ $1-85343-430-2 \mathrm{~h} / \mathrm{b} \$ 55.00$

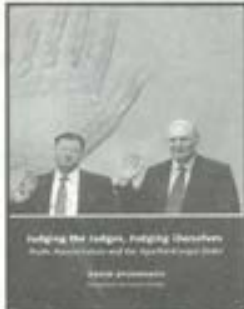

Judging the Judging, Judging Ourselves: Truth, Reconciliation \& the Apartheid Legal Order 1-901362-94-9 h/b $\$ 30.00$

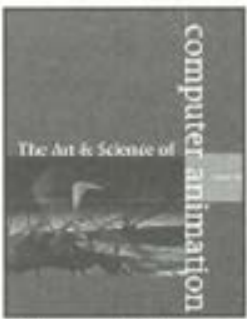

The Art \& Science of Computer Animation 1-871516-71-4 p/b \$34.95

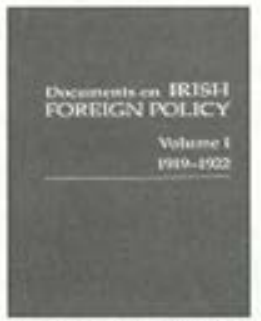

Documents on Irish Foreign Policy v. 1 1919-1922 1-874045-63-1 h/b $\$ 46.50$ 

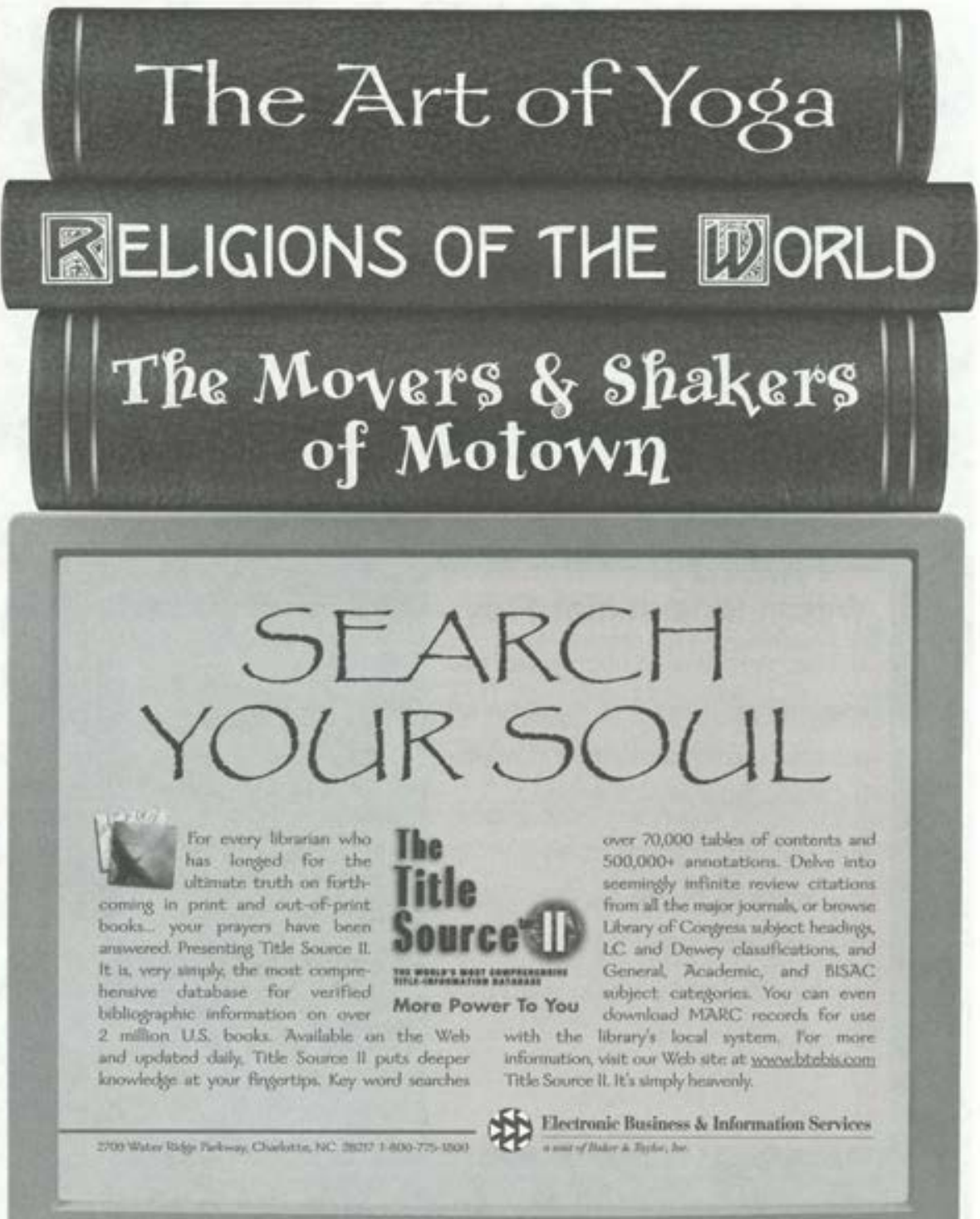

$\square$

Visit us at Booth \# 231 at the ACRL Conference in Detroit 


\section{Because people continue to reach}

\section{new heights...}

\section{-}

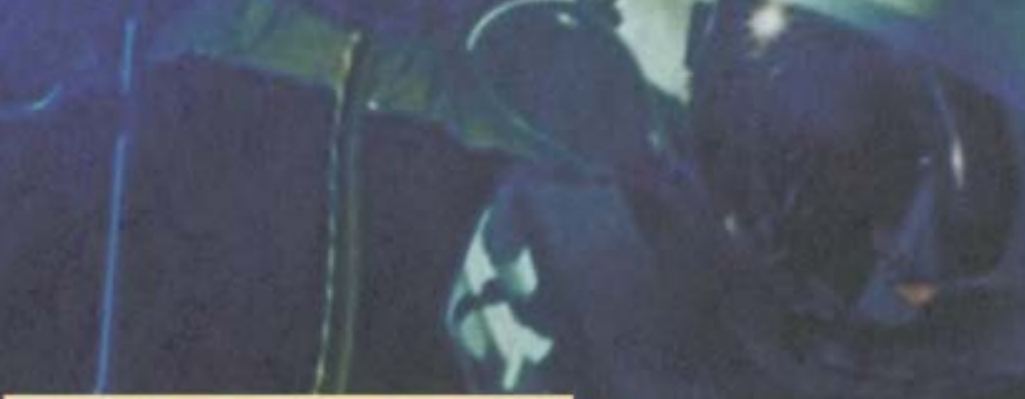

\section{Wilson Biographies Plus}

features more than 45,000 profiles, plus

constantly expanding links to related full text articles, article abstracts, or index citations appearing in some 4,000 sources. Even profiles of historical figures grow this way, as new information comes to light on their lives and works. What's more, the database is updated with approximately 80 new profiles per month.

January, 1999. Web database.

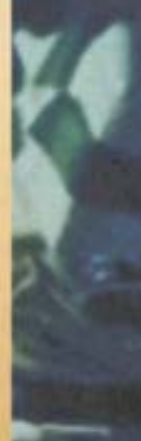

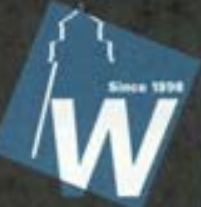

New York Dublin

\section{H.W. Wilson}

Information for tomorrow, today 950 University Avenue • Bronx, NY 10452-4224 Call 800-367-6770; Outside of the U.S, and Canada Call 718588 8400 Fax 800-590-1617; Outside of the U.S, and Canada Fax 718.590-1617 E-mail: custservohwwilson.com - Internet: www.hwwilson.com 